\title{
Corrosion Resistance of Heat-Treated NST 37-2 Steel in Hydrochloric Acid Solution
}

\author{
David Abimbola Fadare*, Taiwo Gbolarumi Fadara \\ Mechanical Engineering Department, University of Ibadan, P.M.B 1, Ibadan, Nigeria \\ Email: *fadareda@yahoo.com
}

Received July 20, 2012; revised August 27, 2012; accepted September 10, 2012

\begin{abstract}
Corrosion of metal components constitutes a major challenge in many engineering systems, with appropriate design, proper material selection, and heat treatment as commonly used control strategies. In this study, the corrosion behaviour of heat-treated (annealed, normalised, hardened, and tempered) NST 37-2 steel in three concentrations (1.0, 1.5 and 2.0 M) of hydrochloric acid solution was investigated using weight loss and electrode-potential methods. Results showed that corrosion rate increased with increase in acid concentration. The decreasing order of corrosion resistance was Tempered $>$ Annealed $>$ Normalised $>$ Hardened $>$ Untreated. The surface pictures of the heat-treated and untreated samples showed uniform and pitting corrosion with the latter becoming more pronounced as concentration increased.
\end{abstract}

Keywords: Heat Treatment; Corrosion Resistance; Hydrochloric Acid; NST 37-2 Steel

\section{Introduction}

Corrosion of metal components has been recognized as a major problem in many engineering applications. Failure of engineering systems due to corrosion is as common as failure due to mechanical causes such as brittle fracture and fatigue. The annual cost of corrosion for the US and UK has been estimated at about $\$ 70$ billion accounting for about $4 \%$ of the national Gross Domestic Product (GDP) [1]. This estimate may well be higher in some less developed countries, although it is probably less in the least developed countries [2]. About $15 \%-25 \%$ of the annual global steel production is estimated to be used for repair or replacement of damages due to corrosion [3]. Corrosion failures are minimized by appropriate design, proper material selection, control of metallurgical structure through heat treatment and use of inhibitors. Of all these control strategies, heat treatment is most commonly used due to its cost effectiveness.

Annealing, normalising, hardening and tempering are the most commonly used heat treatment of carbon steels. Annealing is most frequently applied in order to soften carbon steel materials and refines its grains due to ferritepearlite microstructure $[4,5]$. In normalising, the material is heated to the austenitic temperature range and this is followed by air cooling to obtain a mainly pearlite matrix, which results into increase in strength and hardness [6]. In hardening, the material is heated to a temperature high enough to promote the formation of austenite, held at that

"Corresponding author. temperature until the desired amount of carbon has been dissolved and then quench in oil or water at a suitable rate to obtain $100 \%$ martensite with maximum yield strength, but it is very brittle and thus quenched steels are used for very few engineering applications. By tempering, the properties of quenched steel are modified to decrease hardness, increase ductility and impact strength moderately, resulting microstructures are bainite or carbide precipitate in a matrix of ferrite depending on the tempering temperature.

Investigations on the effects of heat treatment on the corrosion behavior of different carbon steel materials have been reported by many researchers. In particular, the effects of heat treatment on corrosion behaviour of AISI 403 martensitic stainless steel [7], AISI 420 martensitic stainless steel [8], AISI 52100 steel [9], 304 L stainless steel $[10],{ }^{14} \mathrm{Cr}-{ }^{3} \mathrm{Mo}$ martensitic stainless steel [11] have been reported. Corrosion behavior of different carbon steel materials in different media typical of the in-service environments has also been investigated by many researchers. Acidic environment are generally encountered in many industrial processes. Acid solutions are used especially for the removal of undesirable scales and rust from carbon steel materials. Particularly, hydrochloric acid are widely used for the picking processes of metals [12]. Corrosion behavior of numerous grades of carbon steels in hydrochloric acid solutions has been widely studied by many researchers [13-18]. However, there are numerous studies on the effect of heat treatment of carbon steel grades on the corrosion behaviour in 
hydrochloric acid solutions. Strobel et al. [3] reported the effect of the heat treatment on the corrosion resistance of a martinsitic stainless steel CA6NM in $\mathrm{HCl}$ solutions, while Al-Quran and Al-Itawi [19] reported an increase in the corrosion resistance of chromium-nickel alloy steel in $0.1 \mathrm{M} \mathrm{HCl}$ solution due to intermediate spheroidal annealing.

NST 37-2 steel is a commercially available carbon steel grade locally produced by the Delta Steel Company (DSC) located at Ovwian-Aladja, Warri, Delta State, Nigeria. DSC is the only operational integrated steel plant producing steel from basic raw in the south of the Sahara and West Africa [20]. Its steel production capacity is expected to hit 2.4 Million Tonnes Per Annum (MTPA) by 2015 from the current 1.0 MTPA [20]. About 320,000 tonnes per annum of the steel produced is rolled into light sections such as: flats, channels, angles, I-Beams and square bars, and also as plain and ribbed bars of different dimensions [20]. NST 37-2 steel is widely used as construction materials in building, road, and bridge constructions, and as well as in fabrication of machinery and manufacturing of machine components [21]. NST $37-2$ steel constitutes one of the mostly used steel in the Nigerian construction industry for reasons of its versatility, strength, toughness, low cost and wide availability $[22,23]$.

Although, investigations on the heat treat ability and mechanical property enhancement of NST 37-2 steel are few in literature. The effect of heat treatment on the microstructure and mechanical properties has been reported by Fadare et al. [24], while the effect of heat treatment on the fatigue behaviour has been reported by Malomo et al. [25]. Studies on the machinability of NST 37-2 steel have also been reported by Fadare and Ashafa [26,27].

Previous studies on NST 37-2 steel were focused mainly on the microstructure and mechanical property improvement. However, the effect of heat treatment on the corrosion behavior has not been reported. Hence, the objective of this study is to investigate the effect of heat treatment (annealing, normalising, hardening, and tempering) on the corrosion resistance of NST 37-2 steel in 1.0, 1.5 and $2.0 \mathrm{M} \mathrm{HCl}$ solutions.

\section{Materials and Method}

\subsection{Sample Preparation}

Samples of hot-rolled, $16 \mathrm{~mm}$ diameter, NST 37-2 steel bars were purchased from a local market in Lagos, southwestern Nigeria. The chemical composition of the steel sample as determined by optical emission spectrophotometer is given in Table 1, while the mechanical properties and microstructure of the as-received sample are given in Table 2 and Figure 1, respectively. Cylindrical coupons $(\mathrm{Q} 16 \times 25) \mathrm{mm}$ dimensions were machined from the sample and subjected to four commonly used industrial heat treatment processes for carbon steels: annealing, normalising, hardening, and tempering in accordance to American Society of Materials (ASM) International Standards [28]. The heat treatment conditions applied are listed in Table 3. The heat treated and the as-received (untreated) samples were washed in $\mathrm{HCl}$ solution and rinsed in distilled water to remove scale formulation on the samples prior to the corrosion test.

Table 1. Chemical composition of the as-received NST 37-2 steel.

\begin{tabular}{llllllll}
\hline $\mathrm{C}(\%)$ & $\mathrm{Si}(\%)$ & $\mathrm{S}(\%)$ & $\mathrm{P}(\%)$ & $\mathrm{Mn}(\%)$ & $\mathrm{Ni}(\%)$ & $\mathrm{Cr}(\%)$ & $\mathrm{Mo} \mathrm{( \% )}$ \\
\hline 0.3422 & 0.2020 & 0.0108 & 0.0049 & 0.7374 & 0.0067 & 0.0104 & 0.0011 \\
$\mathrm{Zn}(\%)$ & $\mathrm{As}(\%)$ & $\mathrm{Sn}(\%)$ & $\mathrm{Al}(\%)$ & $\mathrm{Fe}(\%)$ & $\mathrm{Cu}(\%)$ & $\mathrm{V}(\%)$ & \\
0.0013 & 0.0005 & 0.0022 & 0.0013 & 98.6824 & 0.0033 & 0.0006 & \\
\hline
\end{tabular}

Table 2. Mechanical properties of the as-received NST 37-2 steel.

\begin{tabular}{cc}
\hline Properties & Average Value \\
\hline Yield Strength $\left(\mathrm{MN} / \mathrm{m}^{2}\right)$ & 245.41 \\
Tensile Strength $\left(\mathrm{MN} / \mathrm{m}^{2}\right)$ & 342.33 \\
Elongation (\%) & 18.48 \\
Reduction in Area (\%) & 15.05 \\
Young Modulus (GPa) & 198.50 \\
Hardness (BHN) & 48.50 \\
Density $\left(\mathrm{g} / \mathrm{cm}^{3}\right)$ & 8.15 \\
\hline
\end{tabular}

Table 3. Heat treatment conditions.

\begin{tabular}{ccccc}
\hline Condition & Annealed & Normalized & Hardened & Tempered \\
\hline Temperature $\left({ }^{\circ} \mathrm{C}\right)$ & 910 & 910 & 910 & 450 \\
Holding Time $(\mathrm{min})$ & 90 & 90 & 40 & 90 \\
Cooling Medium & Furnace & Air & Water & Air \\
\hline
\end{tabular}

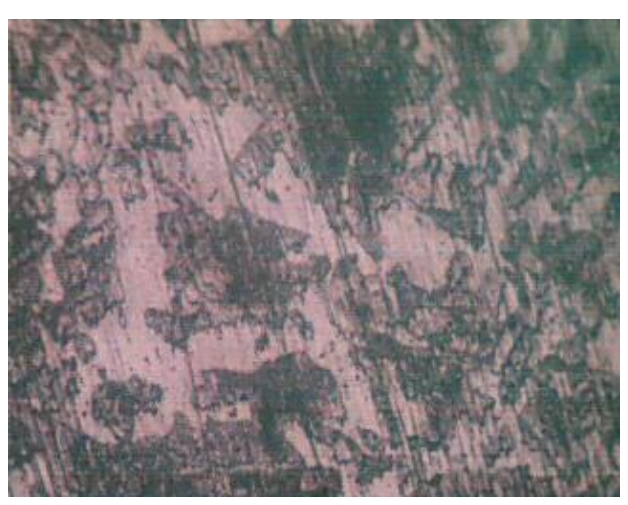

Figure 1. Microstructure of the as-received NST 37-2 steel (400×) (Source: Fadare et al. [24]). 


\subsection{Corrosion Test}

Electrolyte solutions consisting of $1.0,1.5$, and $2.0 \mathrm{M}$ $\mathrm{HCl}$ were prepared with distilled water. The heat-treated and untreated (control) coupons were weighed using a digital balance with accuracy of $\pm 0.0001 \mathrm{~g}$. Copper wire (electrical conductor) was brazed on the surface of each coupon and used as working electrode, while $\mathrm{Ag} / \mathrm{AgCl}(\mathrm{s}) /$ $\mathrm{KCl}$ saturated (aq) half-cell was used as the reference electrode. Complete immersion test was carried out using mass loss and electrode potential methods for 120 hours (five days) duration on a corrosion rig consisting of nine (9) corrosion cells. Each corrosion cell consisted of a beaker containing $400 \mathrm{~mL}$ of the electrolyte solution, test coupons with conducting wire, reference electrode, glass tube for air bubbles circulation and a plastic lid (Figure 2). The test solution temperature was maintained at room temperature $\left(28^{\circ} \mathrm{C}-32^{\circ} \mathrm{C}\right)$. The electrode potential of the cell was taken at 6 hours interval using a digital multimeter at a sweep rate of $20 \mathrm{mV}$, while mass loss of the coupon was measured daily. Compressed air was bubbled through the electrolyte via glass tube suspended at the centre of each cell for purposes of oxygen circulation and agitation of the medium. The heat-treated and untreated coupons were placed together in random order in each of the three (3) cells containing difference concentrations (1.0, 1.5 and $2.0 \mathrm{M})$ of the test solution.

The experiment was replicated in triplicate given rise to nine (9) cells. After each exposure time the coupons were removed from the cells, properly cleaned in distilled water, dried with cotton wool and then reweighed to determine the mass loss. The average mass loss was determined and the corrosion rate in millimetre penetration per year $(\mathrm{mm} / \mathrm{y})$ was calculated using the following relationship [18]:

$$
\text { corrosion rate }\left(\frac{\mathrm{mm}}{y}\right)=\frac{87.6 \times W_{\text {loss }}}{a \times \rho \times t}
$$

where $W_{\text {loss }}=$ mass loss (mg), $a=$ total exposed area of coupon $\left(\mathrm{cm}^{2}\right), t=$ duration of immersion (hours) and $\rho=$ material density $\left(\mathrm{g} / \mathrm{cm}^{3}\right)$. Density for NST 37-2 steel $(\rho=$ $\left.8.15 \mathrm{~g} / \mathrm{cm}^{3}\right)$ as given in Table 2 was used in the computation.

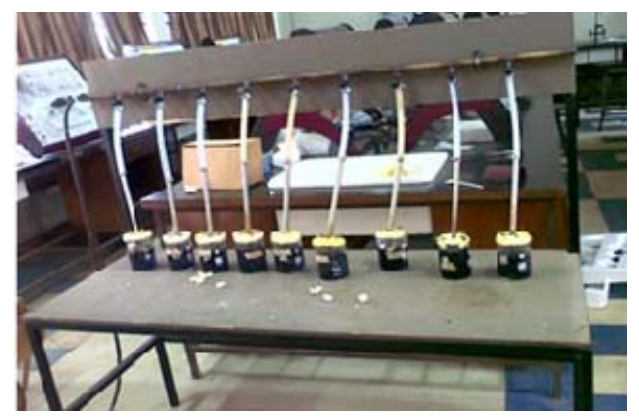

Figure 2. Experimental set-up.

\section{Results and Discussion}

The electrode potential $(\mathrm{mV})$ and corrosion rate $(\mathrm{mm} / \mathrm{y})$ of heat-treated and untreated NST 37-2 steel coupons immersed in 1.0, 1.5 and $2.0 \mathrm{M} \mathrm{HCl}$ solutions are shown in Figure 3 and Table 4, respectively. Generally, the electrode potential of both heat-treated and untreated samples increased linearly with increase in acid concentration and time of immersion in test solution, while the corrosion rate increased linearly with increase in concentration but varied nonlinearly with time of immersion in test solution. The observed linear increase in both electrode potential and corrosion rate with increasing acid concentration of the test solution can be attributed to increase in ion exchange capacity of acid at high concentrations.

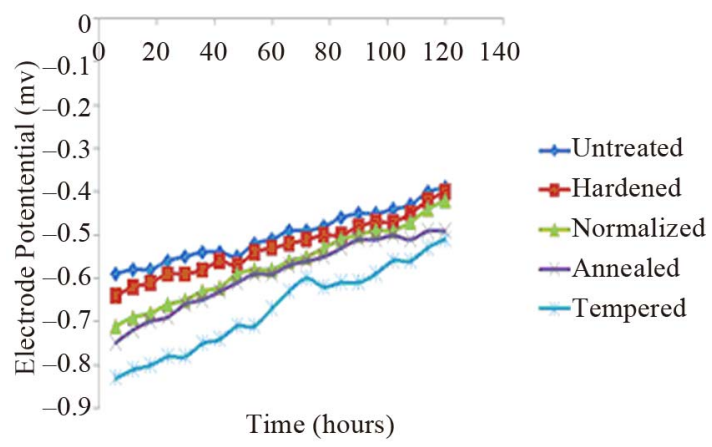

(a)

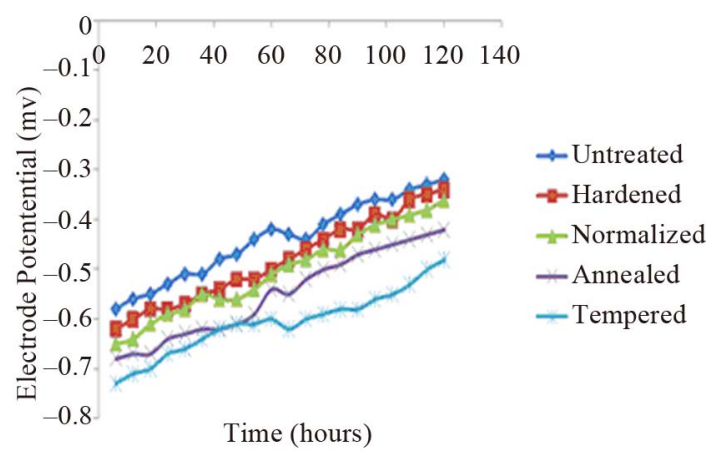

(b)

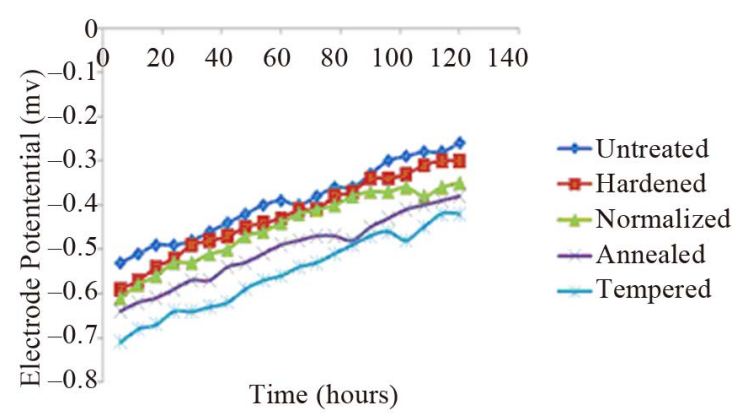

(c)

Figure 3. Variation of electrode potential $(\mathrm{mV})$ of heattreated and untreated NST 37-2 steel in 1.0 M (a), 1.5 M (b) and 2.0 M (c) $\mathrm{HCl}$ solutions with exposure time. 
Table 4. Corrosion rate $(\mathrm{mm} / \mathrm{y})$ of untreated and heat-treated NST 37-2 steel immersed in different concentrations of HCl solution.

\begin{tabular}{|c|c|c|c|c|c|c|}
\hline \multirow{2}{*}{ Concentration } & \multirow{2}{*}{ Time (Hours) } & \multicolumn{5}{|c|}{ Corrosion Rate $(\mathrm{mm} / \mathrm{y})$} \\
\hline & & Untreated & Hardened & Normalized & Annealed & Tempered \\
\hline \multirow{6}{*}{1.0} & 0 & 0.00 & 0.00 & 0.00 & 0.00 & 0.00 \\
\hline & 24 & 27.90 & 25.20 & 20.70 & 19.80 & 17.10 \\
\hline & 48 & 22.05 & 18.45 & 15.30 & 13.95 & 11.70 \\
\hline & 72 & 20.40 & 18.00 & 15.30 & 10.50 & 9.90 \\
\hline & 96 & 18.22 & 16.65 & 14.62 & 10.57 & 7.65 \\
\hline & 120 & 16.92 & 14.22 & 12.96 & 10.26 & 6.66 \\
\hline \multirow{5}{*}{1.5} & 0 & 0.00 & 0.00 & 0.00 & 0.00 & 0.00 \\
\hline & 24 & 49.49 & 39.59 & 33.29 & 30.60 & 27.90 \\
\hline & 48 & 31.05 & 26.10 & 23.85 & 20.25 & 17.55 \\
\hline & 72 & 24.90 & 21.60 & 19.80 & 17.70 & 14.40 \\
\hline & 96 & 21.82 & 18.67 & 16.42 & 14.85 & 12.15 \\
\hline \multirow{7}{*}{2.0} & 120 & 20.16 & 18.54 & 16.38 & 14.04 & 12.78 \\
\hline & 0 & 0.00 & 0.00 & 0.00 & 0.00 & 0.00 \\
\hline & 24 & 68.39 & 61.19 & 48.59 & 43.19 & 39.59 \\
\hline & 48 & 44.99 & 37.34 & 31.94 & 25.65 & 22.95 \\
\hline & 72 & 35.99 & 28.50 & 26.40 & 21.30 & 18.90 \\
\hline & 96 & 31.94 & 25.42 & 22.72 & 19.57 & 17.77 \\
\hline & 120 & 29.34 & 27.00 & 25.20 & 19.08 & 17.64 \\
\hline
\end{tabular}

The electrode potential tended to be more positive (anodic) with increase in concentration of test solution and time of immersion. The increased positivity led to corresponding increase in the electromotive force (corrosion current) between the working (anode) and reference (cathode) electrodes and hence accelerated corrosion of the anode (test material). It can be observed that the electrode potential of the untreated sample tended to be more positive consistently in all the three acid concentrations of the test solution followed by the heat-treated samples in decreasing order: hardened, normalized, annealed and tempered. On the other hand, the corrosion rate of the heat-treated and untreated NST 37-2 steel coupons in different concentrations of $\mathrm{HCl}$ solution are shown in Table 4.

Both heat-treated and untreated samples varied nonlinearly with time of immersion in the test solution. The corrosion rates increased rapidly during the first 24 hours (1 day) of immersion, after which it began to decline progressively with time. This nonlinear trend in the corrosion curve may be attributed to the surface passivation of the carbon steel, in which the formation of rust on the attacked region of the steel tends to form a protective layer on the surface, thus protecting the parent material from further attack. Since rust formation is known to be water and oxygen permeable, the passivity of the surface tends to breakdown progressively, hence resulting in reduction in corrosion rate of the material. Similarly, nonlinear trends in corrosion-time curves of 18/8 stainless steel and nickel-plated low carbon steel in cassava fluid
[29], and mild steel and SS 304L in presence of dissolved copper [30] have been reported by other researchers. In contrast, linear relationship has been reported for chromium-nickel alloy steel in $0.1 \mathrm{M} \mathrm{HCl}$ solution [19]. The discrepancy in these observations may be attributed to disparity in the elemental composition of the parent alloy materials.

Similarly, in same order with the observed electrode potential trends, the untreated sample showed the highest corrosion rate in all the three acid concentrations of the test solution, followed by the heat-treated samples in decreasing order: hardened, normalized, annealed and tempered, thus indicating that the heat treatment processes tend to improve the corrosion resistance of NST 37-2 steel in $\mathrm{HCl}$ solutions. Hence, the microstructural evolution of the material during the heat treatment processes played a fundamental role on the corrosion behavour of the material. The effects of these heat treatment processes (annealing, normalising, hardening, and tempering) on the microstructural evolution and mechanical properties of the material have been reported earlier [24]. The ferritic + pearlitic matrix microstructure of the as-received (untreated) sample tends to increase the dissimilar metal composition of the material, leading to galvanic corrosion and hence, the accelerated corrosion rate observed in the untreated sample. The martensitic matrix of the hardened sample tends to be more corrosion resistant than the dual-phase matrix of the untreated sample. Similarly, Keleștemur and Yıldız [31] has reported that intercritical annealing heat treatments of 
dualphase steel embedded in concrete has a good corrosion resistance which increased with increase amount of martensite microstructure in the steel. The single-phase pearlitic and ferritic matrix of the normalised and annealed samples respectively tend to be more corrosion resistance compared to the dual-phase of the untreated sample, while the dual-phase martensitic and ferritic matrix of the tempered sample tends to be more corrosion resistance than both the single-phase martensite and fer- rite microstructure of the hardened and annealed samples respectively. Lucio-Garcia et al. [32] has shown that the steel with a martensitic microstructure had the highest corrosion rate; up to one order of magnitude higher than the corrosion rate for steels with a ferritic and bainitic microstructure, whereas the steel with the ferritic microstructure showed the lowest corrosion rate.

The surface scan of the corroded surface (Figure 4) revealed that both uniform and pitting corrosion occurred

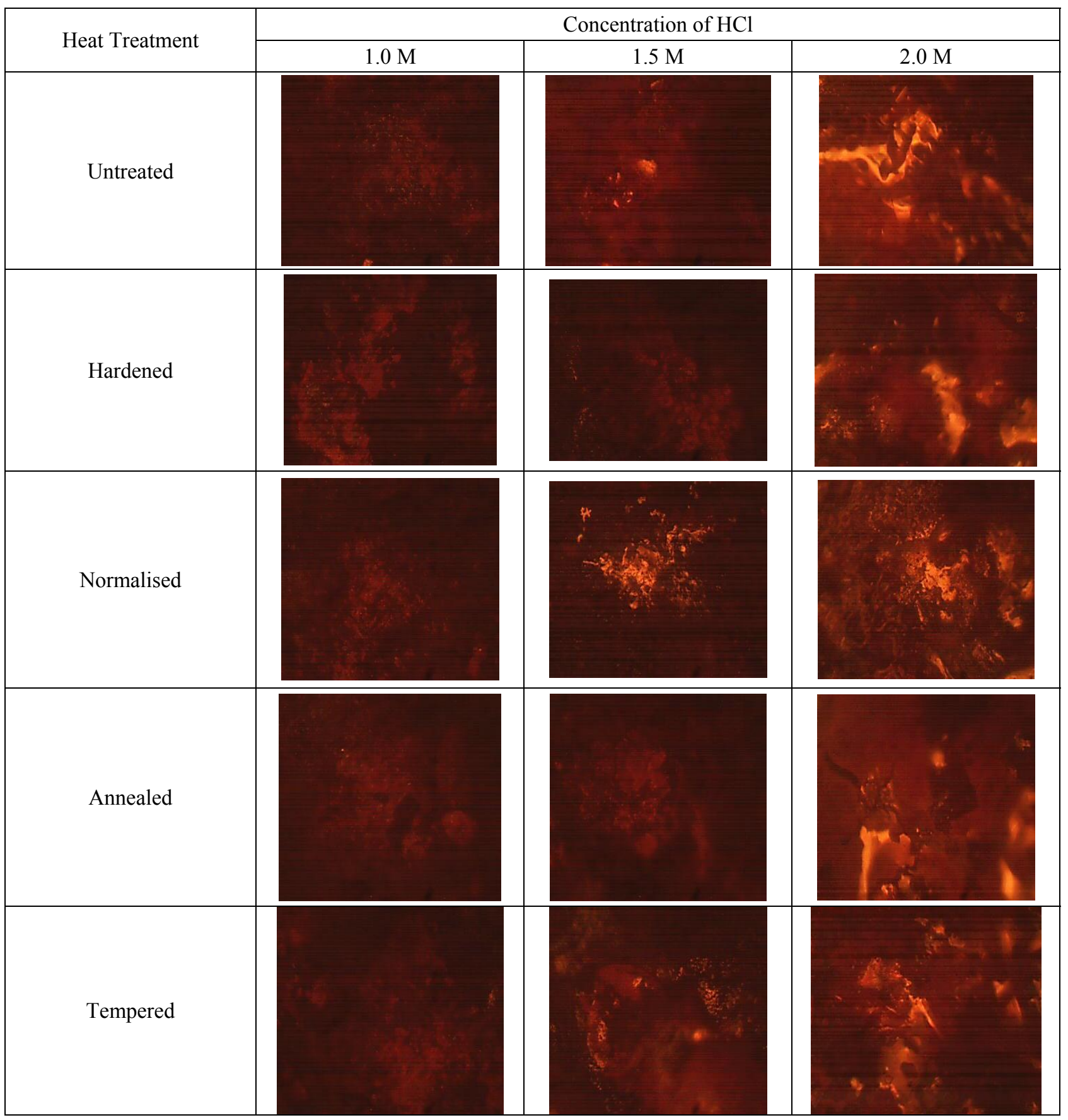

Figure 4. Surface scan of the corroded heat-treated and untreated NST 37-2 steel coupons different concentrations of hydrochloric acid solution. 
on the samples.

\section{Conclusion}

The effect of heat treatment on corrosion resistance of NST 37-2 steel in $\mathrm{HCl}$ solutions has been investigated. The analysis showed that both corrosion rates and electrode potentials of the untreated sample had the highest corrosion rate and shifted more to the positive values as the concentration of acid was increased. For the heat treated samples, the corrosion rate in the test solutions ranked in decreasing order: hardened, normalized, annealed and tempered.

\section{Acknowledgements}

We are grateful to an anonymous referee for helpful comments. We also wish to thank Kim Humphreys for English editing. All errors are ours.

\section{REFERENCES}

[1] V. P. Pludek, "Design and Corrosion," Wiley, New York, 1977.

[2] L. L. Shreir, R. A. Jarman and G. T. Burstein, "Design and Economic Aspects of Corrosion," Corrosion, Vol. 2, No. 9, 2000, p. 1478.

[3] E. F. Strobel, N. A. Mariano, K. Strobel and M. F. Dionízio, "Effect of the Heat Treatment in the Resistance Corrosion of a Martinsitic Stainless Steel CA6NM," 2nd Edition, Mercosur Congress on Chemical Engineering, 2012.

http://www.enpromer2005.eq.ufrj.br/lng/en/index.php

[4] M. H. A. Kempester, "Materials for Engineers", 3rd Edition, Hoodder and Stonghton, London, 1984.

[5] A. Raymond and B. Higgins, "Properties of Engineering Materials," Hoodder and Stonghton, London, 1985.

[6] K. A. Dell, "Metallurgy Theory and Practical Textbook," American Technical Society, Chicago, 1989.

[7] J. G. Gonzalez-Rodriguez, G. Bahena-Martinez and V. M. Salinas-Bravo, "Effect of Heat Treatment on the Stress Corrosion Cracking Behaviour of 403 Stainless Steel in $\mathrm{NaCl}$ at $95^{\circ} \mathrm{C}$," Materials Letters, Vol. 43, No. 4, 2000, pp. 208-214. doi:10.1016/S0167-577X(99)00261-X

[8] A. N. Isfahany, H. Saghafian and G. Borhani, "The Effect of Heat Treatment on Mechanical Properties and Corrosion Behaviour of AISI 420 Martensitic Stainless Steel," Journal of Alloys and Compounds, Vol. 509, No. 9, 2011, pp. 3931-3936. doi:10.1016/j.jallcom.2010.12.174

[9] J. Xie, A. T. Alpas and D. O. Northwood, "The Role of Heat Treatment on the Erosion-Corrosion Behaviour of AISI 52100 Steel," Materials Science and Engineering: A, Vol. 393, No. 1-2, 2005, pp. 42-50. doi:10.1016/j.msea.2004.09.045

[10] O. V. Akgün, M. Ürgen and A. F. Çakir, "The Effect of Heat Treatment on Corrosion Behaviour of Laser Surface Melted 304L Stainless Steel," Materials Science and Engi- neering: $A$, Vol. 203, No. 1-2, 1995, pp. 324-331. doi:10.1016/0921-5093(95)09807-0

[11] J. Park and Y. Park, "The Effects of Heat-Treatment Para- meters on Corrosion Resistance and Phase Transformations of 14Cr-3Mo Martensitic Stainless Steel," Materials Science and Engineering: A, Vol. 449-451, 2007, pp. 1131-1134. doi:10.1016/j.msea.2006.03.134

[12] A. A. Khadom, A. S. Yaro, A. S. AlTaie and A. A. H. Kadum, "Electrochemical, Activation and Adsorption for the Corrosion Inhibition of Low Carbon Steel in Acidic Media," Portugaliae Electrochimica Acta, Vol. 27, No. 6, 2009, pp. 699-712. doi:10.4152/pea.200906699

[13] L. Herrag, B. Hammouti, S. Elkadiri, A. Aouniti, C. Jama, H. Vezin and F. Bentiss, "Adsorption Properties and Inhibition of Mild Steel Corrosion in Hydrochloric Solution by Some Newly Synthesized Diamine Derivatives," Experimental and Theoretical Investigations, Corrosion Science, Vol. 52, No. 9, 2010, pp.3042-3051. doi:10.1016/j.corsci.2010.05.024

[14] D. Jayaperumal, "Effects of Alcohol-Based Inhibitors on Corrosion of Mild Steel in Hydrochloric Acid," Materials Chemistry and Physics, Vol. 119, No. 3, 2010, pp. 478484. doi:10.1016/j.matchemphys.2009.09.028

[15] J. Aljourani, M. A. Golozar and K. Raeissi, "The Inhibition of Carbon Steel Corrosion in Hydrochloric and Sulfuric Acid Media Using Some Benzimidazole Derivatives," Materials Chemistry and Physics, Vol. 121, No. 1-2, 2010, pp. 320-325. doi:10.1016/j.matchemphys.2010.01.040

[16] A. K. Singh and M. A. Quraishi, "Investigation of the Effect of Disulfiram on Corrosion of Mild Steel in Hydrochloric Acid Solution," Corrosion Science, Vol. 53, No. 4, 2010, pp. 1288-1297. doi:10.1016/j.corsci.2011.01.002

[17] N. A. Negm, Y. M. Elkholy, M. K. Zahran and S. M. Tawfik, "Corrosion Inhibition Efficiency and Surface Activity of Benzothiazol-3-Ium Cationic Schiff Base Derivatives in Hydrochloric Acid," Corrosion Science, Vol. 52, No. 10, 2010, pp. 3523-3536. doi:10.1016/j.corsci.2010.07.001

[18] A. K. Singh and M. A. Quraishi, "Investigation of Adsorption of Isoniazid Derivatives at Mild Steel/Hydrochloric Acid Interface: Electrochemical and Weight Loss Methods," Materials Chemistry and Physics, Vol. 123, No. 2-3, 2010, pp. 666-677. doi:10.1016/j.matchemphys.2010.05.035

[19] F. M. F. Al-Quran and H. I. Al-Itawi, "Effects of the Heat Treatment on Corrosion Resistance and Microhardness of Alloy Steel," European Journal of Scientific Research, Vol. 39, No. 2, 2010, pp. 251-256.

[20] A. Chiejina, "Revamping the Fortunes of Delta Steel Company (DSC)," 2011. http://businessdayonline.com/ng/index.php/analysis/featu res/23505-revamping-the-fortunes-of-delta-steel-company

[21] NSE (Nigerian Society of Engineers), "Professional Development Board Codes and Ethics Committee," A Report on Workshop on Evaluation of Engineering Standards, Nigeria, 17-18 October 2001, pp. 1-32. 
[22] S. O. Jakayinfa, J. O. Ojediran and P. O. Okekunle, "An Evaluation of Corrosion Prevention Practices in Agricultural Equipment Manu-facture and Used in Nigeria," $A n-$ ti-Corrosion Materials, Vol. 54, No. 5, 2003, pp. 346370.

[23] S. E. Chukwujekwu, "Locally Designed and Manufactured Goods: Prospects for Third Millennium in Nigeria," A Paper Presented at the COREN Engineering Assembly, 1998, pp. 40-68.

[24] D. A. Fadare, T. G. Fadara and O. Y. Akanbi, "Effect of Heat Treatment on Mechanical Properties and Microstructure of NST 37-2 Steel," Journal of Minerals and Materials Characterization and Engineering, Vol. 10, No. 3, 2011, pp. 299-308.

[25] B. O. Malomo, S. A. Ibitoye and L. O. Adekoya, "The Analysis of the Fatigue Behaviour of NST 37-2 Steel Based on the Probabilistic Stress-Life (P-S-N) Relationships," Proceedings of the Faculty of Technology International Conference, Obafemi Awolowo University, Ile-Ife, 25-29 September 2011, pp. 164-174.

[26] D. A. Fadare and T. B. Asafa, "Optimization of Turning NST 37-2 Steel with Uncoated Carbide Cutting Tools," Journal of the Nigerian Institution of Mechanical Engineers, Vol. 2, No. 1, 2010, pp. 31-40.

[27] D. A. Fadare and T. B. Asafa, "Performance Evaluation of Uncoated Carbide Cutting Tools in Turning NST 37-2
Steel," Proceedings of 22nd International Conference of the NIMechE, Osogbo, 20-22 October 2009, pp. 20-24.

[28] ASM (American Society for Metals) "International ASM Handbook Vol. 4: Heat Treatment," Park, Ohio, 1991.

[29] O. O. Oluwole, P. O. Atanda, O. A. Odekunbi and E. Odegbaju, "Corrosion Behavior of 18/8 Stain-Less Steel and Nickel-plated Low Carbon Steel in Cassava Fluid," Journal of Minerals \& Materials Characterization \& Engineering, Vol. 8, No. 10, 2009, pp. 803-811.

[30] M. Mobin and H. Shabnam, "Corrosion Behavior of Mild Steel and SS 304L in Presence of Dissolved Copper," Journal of Minerals \& Materials Characterization \& Engineering, Vol. 9, No. 12, 2010, pp.1113-1130.

[31] O. Keleştemur and S. Yıldız, "Effect of Various DualPhase Heat Treatments on the Corrosion Behaviour of Reinforcing Steel Used in the Reinforced Concrete Structures," Construction and Building Materials, Vol. 23, No. 1, 2009, pp. 78-84. doi:10.1016/j.conbuildmat.2008.02.001

[32] M. A. Lucio-Garcia, J. G. Gonzalez-Rodriguez, M. Casales, L. Martinez, J. G. Chacon-Nava, M. A. Neri-Flores and A. Martinez-Villafañe, "Effect of Heat Treatment on $\mathrm{H}_{2} \mathrm{~S}$ Corrosion of a Mcro-alloyed C-Mn Steel," Corrosion Science, Vol. 51, No. 10, 2009, pp. 2380-2386. doi:10.1016/j.corsci.2009.06.022 